\title{
Ecological and economic education: as the basis for the formation of modern relations
}

\author{
E.A. Krasnoperova* \\ FSBEE HE South Ural state agrarian University, Troitsk, Russia
}

\begin{abstract}
The strategic direction of the greening of agricultural production is the education and formation of appropriate thinking of all groups of the population. The article deals with the essence of environmental education, and the education of rural residents as a continuous process. This process begins at an early age and ends with a period when a person shares the acquired and accumulated knowledge and experience with young people. We distinguish five stages of the formation of knowledge and experience throughout his life. Each of the designated stages has its own goal and objectives and different duration.
\end{abstract}

\section{Introduction}

The relevance of this study is due to the following circumstances. First, it should be noted that over the past 50-70 years, the anthropogenic impact on natural objects has increased dramatically, and the production of hydrocarbons and other minerals has increased significantly. Deep cuts from surface mining have appeared on the body of the Earth. For example, near the city of Korkino, Chelyabinsk region, for many years, coal was extracted by open-pit mining, after coal mining stopped, a quarry with a depth of more than 400 meters was formed. There are constantly observed underground fires from the developed layers of coal. The area of the quarry is constantly expanding due to the shedding of the edges, as a result of which entire settlements are relocated. Until now, the negative consequences of the accident on "Mayak" and others are still evident.

Secondly, over the past two or three decades, the number of cars has increased dramatically, and gas-engine fuel emissions are poisoning the atmosphere of large cities and large industrial centers [1-5].

Third, the production of plastics and their products has become widespread in recent years. Plastic waste does not decompose for decades or centuries. Meanwhile, and can be used as a raw material for the development of new products. However, waste collection is poorly organized.

Fourth, industrial and household waste has become a scourge for present and future generations. On the one hand, the area under landfills is constantly increasing, reducing due to the allocation of agricultural land for their storage [6, 8, 10-15].

Fifth, agriculture and agriculture have become powerful pollutants of air and water

\footnotetext{
*Corresponding author: EA.G@mail.ru
} 
basins. The high concentration of livestock and poultry on limited land increases the risk of the spread of infectious and non-infectious diseases.

Therefore, agricultural producers use a large number of deodorants, veterinary drugs, which enter the atmosphere through ventilation. This explains the high incidence of acute respiratory infections in the population within a radius of $3-5 \mathrm{~km}$ from the source of distribution [7]. In addition, the removal of manure is carried out by hydro-washing and enters the ponds of the sedimentation tanks. Further advancement of liquid fractions is difficult to foresee, as they fall into underground water sources. Bird droppings can become a powerful contaminant of land and the spread of stench. Currently, there are technologies for processing bird droppings into organic granular fertilizers. However, drying the litter and its granulation is an expensive measure, the management of poultry farms is not interested in this. For them, the existing fines are cheaper than opening a new production facility. All of the above suggests that the education and upbringing of environmental safety is becoming an urgent problem for many decades to come.

The strategic direction of the greening of agricultural production is the education and formation of appropriate thinking of all groups of the population. Perhaps this direction is more important than the others. We believe that the education of ecological thinking should be formed from an early age, from kindergartens.

The methodology of this study provides a review and analysis of scientific research in different regions of the country.

We consider the essence of ecological and economic education as a continuous process throughout a person's life. In the first stages of life, from kindergarten to graduation, a villager learns the specifics of rural labor, the basics of growing crops and animals. At a more mature age, he receives a special education, gaining working or managerial knowledge and leads to a certain system. Of course, depending on the profession received and the position held, a person must have different amounts of knowledge on technology, economy, environmental management, and other types of knowledge. We consider obtaining relevant knowledge depending on the position held and the professional knowledge gained.

Obviously, the famous chairman of the collective farm named after Frunze of the Belgorod region, V. Ya. Gorin, was right, who forced each garden to have beds with the simplest vegetable crops and flowers. To idle questions about why he does this, the twice Hero of Socialist Labor answered: "That he does not care about vegetables as such, it is important for him that children see and know what kind of vegetables they are and how they are grown. Teachers taught children to take care of flowers and vegetable beds (weeding and watering). The children gradually formed knowledge about a particular plant and its meaning. This contributes to the formation of children's respectful attitude to the results of peasant labor: do not throw pieces of bread, do not throw the remnants of food. Thus, a respectful attitude to agricultural labor, as one of the main types of human activity, is gradually being formed.

\section{Data and Methods}

The object of the study is the ecological and economic processes that characterize the environmental and social aspects, during which modern relations are formed. In the course of the research, economic-statistical, abstract-logical and other methods were used. 


\section{Methods or Model}

The methodology of this study provides a review and analysis of scientific research in different regions of the country. This approach allowed us to identify the stages of environmental education for different age groups and life stages of the population. During school years, knowledge about the nature of rural labor and its features, the importance of production, is gradually deepened, supplemented with new knowledge in general education disciplines (botany, biology, geography). In rural families, children are gradually trained to work, participating in the household and in the household plots. During the most intense periods of field work in the household, older children were involved in hay harvesting. From time immemorial, peasant children grew up in front of the elders in the family, and under their supervision participated in the harvesting of potatoes and vegetables.

At the end of the last century, in a number of regions, rural schools had homestead plots on which garden crops were grown: cucumbers, cabbage, tomatoes, onions, collected from this plot. The harvest was used to organize school meals. Some schools bred rabbits and had apiaries. This practice contributed to the formation of a careful attitude to the results of their work, diversified and reduced the cost of school lunches, that is, it was educational and economic in nature.

In secondary educational schools, high school students helped agricultural enterprises in the care of crops (loosening and weeding sugar beets, weeding and watering vegetable crops). Most likely, this was not of practical importance, but rather serves as an educational process.

High school students were taught to appreciate their own and other people's work, and their knowledge of the cultivation of certain crops was deepened. They were involved in cleaning school premises, painting school desks, etc. Many students willingly took part in these works. Joint work contributed to the awareness of the importance of this work in the team. In the forest regions, the organization of school forestry was practiced, when children participated in the planting of trees and shrubs, took care of them, harvested cones, and the joint work of schoolchildren under the guidance of experienced foresters pursued not only economic goals, but also had an educational character.

The educational function of joint work contributed to the formation of friendly relations for life, formed responsible behavior in the labor collective; here the makings of future managers and organizers of production were identified and formed (the latter regardless of what areas they will work in the future and regardless of where their work activities will take place).

The above-mentioned V. Ya. Gorin annually held the last call with school graduates and met personally with each of them. Together with the school management, he monitored the students ' progress in learning, assessed their organizational skills, and recommended that a particular student choose a profession. All students who entered universities and technical schools received a collective farm scholarship, although many did not choose agricultural specialties. V. Ya. Gorin believed that an engineer, doctor, teacher who did not return to this agricultural enterprise would forever preserve the good memory of the village, school and teachers.

The formation of a respectful attitude to work and its results, in general, to the rural way of life is one of the most important activities of the school. It is no coincidence that many graduates of this high school have achieved great success in various fields of labor and social life. Unfortunately, many historical traditions of education were not in demand with the formation of market relations. School land plots were abandoned or passed into private ownership.Secondary school graduates were not in demand in their villages.

It is almost impossible to find a suitable, feasible job in the village. In many cases, the 
pioneer camps were commercialized and lost their original purpose as measures of collective health improvement for school-age children.

It should also be noted that the education of rural children is somewhat different from the urban one. Rural families have always had a private plot and maintained a subsidiary farm. They grew potatoes, vegetables, berries and fruits on the plot, kept livestock and poultry (a cow, young cattle, one or more pigs or sows with offspring, about a dozen sheep and several dozen young poultry). The maintenance of such a farm required constant employment in the care and supervision of crops, livestock and poultry. On the other hand, there was practically no waste in the household, as small potatoes and vegetables were used for livestock and poultry feed. The same use was found for food waste. The weeded grass was dried and stored for use in winter. Animal waste was used in the household plot, in the garden, as fertilizer. Thus, the cycle of waste was carried out and new involvement of them in the stage of reproduction. Willy-nilly, children were also involved in this process.

The fundamental difference between peasant labor and urban labor is open-air labor, involving it in the biological rhythm of production. Rural labor, unlike urban labor, is closely related to the natural environment, which dictates its own requirements. In agriculture, there are very stressful production processes that need to be carried out in a short time. This means that the working day can last for three or four hours or more in excess of the established norm. Such periods include sowing and harvesting of grain and fodder crops, hay harvesting, sowing operations, transfer of livestock from stable to pasture and vice versa.

During this period, all members of the household, including pensioners and middle-aged and older children, take part in these labor processes as much as possible. It turns out that their labor behavior is dictated by production processes. In winter, the work on caring for livestock increases, but there is no field work. In general, the working day in the household is reduced.

Such a ragged work rhythm does not suit everyone. Naturally, those who are not satisfied with such a labor rhythm leave the village or go to other areas of activity. This is not a tragedy, since all the inhabitants of villages and villages know the specifics of rural labor and appreciate its importance. Often, when they reach retirement age, they return to their permanent place of residence in the village and start a household. At the same time, this trend has been increasing in recent years. We believe that the number of such residents will increase as cities become more urbanized.

Another option of returning to the rural way of life is manifested in the fact that citizens acquire a garden plot, cultivate and take care of the land, growing horticultural crops. Some of these gardeners build capital housing on the garden plot, where they live in it permanently. Children and grandchildren help retired gardeners. At their core, they get acquainted with the specifics of rural life.

Residents of villages are more jealous of the preservation of the natural environment, they protest against unauthorized landfills arranged on the territory of their municipality. They are more balanced about the use of forest and hunting grounds, fishing on rivers and lakes located on the territory of the municipality. These lands bring them additional income through the collection and sale of mushrooms, wild berries, medicinal herbs, fishing and other ancillary industries. This is especially important now, when there is high unemployment in rural areas and the associated decline in real incomes.

Thus, the villagers are closely related to the biological laws of agricultural labor. Their working day starts earlier and ends later. 


\section{Discussion and Conclusion}

The stages of environmental education should correspond to the age and field of activity. We distinguish five main stages from kindergarten to retirement age. In our opinion, the stages of training, education and formation of environmental knowledgeand experience acquisition are presented in the form of the following table.

Table 1. Stages of ecological and economic formation and education of agricultural workers

\begin{tabular}{|c|c|c|c|}
\hline Life span & $\begin{array}{l}\text { Duration of the } \\
\text { period, years }\end{array}$ & $\begin{array}{l}\text { Acquired knowledge and } \\
\text { skills }\end{array}$ & $\begin{array}{l}\text { Place and responsible for } \\
\text { education in the period }\end{array}$ \\
\hline Preschool & $\begin{array}{c}\text { From } 3 \text { to } 7 \text { years } \\
\text { old }\end{array}$ & $\begin{array}{l}\text { Formation of a careful } \\
\text { attitude to the products of } \\
\text { rural labor }\end{array}$ & $\begin{array}{c}\text { Parents and educators of } \\
\text { kindergartens and } \\
\text { nurseries }\end{array}$ \\
\hline $\begin{array}{l}\text { School } \\
\text { District }\end{array}$ & $\begin{array}{c}\text { From } 7 \text { to } 17 \\
\text { years old }\end{array}$ & $\begin{array}{l}\text { Formation of general } \\
\text { knowledge about the } \\
\text { specifics of rural labor }\end{array}$ & $\begin{array}{l}\text { Parents, school teachers, } \\
\text { the public }\end{array}$ \\
\hline $\begin{array}{l}\text { Main work } \\
\text { activity }\end{array}$ & $\begin{array}{l}\text { From } 18 \text { to } 60-65 \\
\text { years old }\end{array}$ & $\begin{array}{l}\text { Formation of professional } \\
\text { knowledge and skills in the } \\
\text { cultivation of individual } \\
\text { crops, breeding of livestock } \\
\text { and poultry, etc. Acquisition } \\
\text { of special knowledge in } \\
\text { secondary vocational } \\
\text { schools, universities }\end{array}$ & $\begin{array}{l}\text { Self-education, teaching } \\
\text { teams of secondary } \\
\text { vocational schools and } \\
\text { universities }\end{array}$ \\
\hline $\begin{array}{l}\text { including } \\
\text { agribusiness } \\
\text { specialists }\end{array}$ & $\begin{array}{l}\text { From } 18 \text { to } 60-65 \\
\text { years old }\end{array}$ & $\begin{array}{l}\text { The ability to identify the } \\
\text { advantages and } \\
\text { disadvantages of different } \\
\text { technologies, conducting } \\
\text { their comprehensive } \\
\text { assessment }\end{array}$ & $\begin{array}{c}\text { University teaching staff, } \\
\text { self-education }\end{array}$ \\
\hline Pension plan & $\begin{array}{l}\text { 60-65 years and } \\
\text { above }\end{array}$ & $\begin{array}{l}\text { Transfer of acquired } \\
\text { knowledge and experience to } \\
\text { children, grandchildren and } \\
\text { other young people, } \\
\text { experimental activities on } \\
\text { their own land plot }\end{array}$ & $\begin{array}{l}\text { self-study and self- } \\
\text { education, older persons }\end{array}$ \\
\hline
\end{tabular}

As can be seen, the initial environmental education and the acquisition of relevant knowledge is carried out in the preschool and school periods. Here, the makings of thinking in relation to human natural objects are formed: land, water, plants and animals. The longest and most productive period is in the main labor activity [4, 7, 9]. At this time, the citizen manifests himself as a person, his organizational and labor abilities are formed, his attitude to natural objects is formed.

As for the work of specialists, they are responsible for the quality of products and raw materials, they organize and control the activities of labor collectives. During this period, specialists and ordinary employees improve their professional skills in schools, at advanced training courses in universities and secondary vocational schools.

At the same time, specialists are involved in obtaining professional knowledge of working professions and middle-level specialists. Once again, we emphasize that the main thing is self-education throughout the entire professional activity. The elderly and pensioners pass on their experience and knowledge to the younger generation, including their children and grandchildren.

Thus, we consider the formation of environmental education and training as a 
continuous process throughout the entire adult life. The main attention should be paid to self-education and self-education.

\section{References}

1. I. Abakumov, Ogonek, 43, 12 (2016) URL: https://www.kommersant.ru/doc/3112925

2. A.N. Galatov, V.G. Litovchenko, E.A. Krasnoperova, V.A. Ivanov, L.M. Glyan'kova, M.Yu. Lunina, Kormlenie sel'skokhozyaystvennykh zhivotnykh i kormoproizvodstvo, 4, 29-35 (2015)

3. A.A. Ermolenko, Vestnik Volgogradskogo gosudarstvennogo universiteta, Seriya Ekonomika, 20(2), 5-15 (2018) DOI: http: // doi.org / 10.15688/ jvolsu 3.2018.2.1.

4. E.A. Krasnoperova, Uchenye zapiski Kazanskoy gosudarstvennoy akademii veterinarnoy meditsiny im N.E. Baumana, 4 (228), 67-71 (2016)

5. E.A. Krasnoperova, Yu.A. Yuldashbaev, Agrarnaya nauka, 3, 2-5 (2016)

6. E.A. Krasnoperova, Vestnik Novosibirskogo gosudarstvennogo agrarnogo universiteta. 3 (44), 164-169 (2017)

7. E.A. Krasnoperova, Yu.A. Yuldashbaev, Trudy Kubanskogo gosudarstvennogo agrarnogo universiteta, 64, 104-109 (2017)

8. E.A. Krasnoperova, Agrarnaya nauka, 5, 86-91 (2020) DOI: 10.32417/1997-4868-2020196-5-86-92.

9. E.A. Krasnoperova, Yu.A. Karmatskikh, Feeding of farm animals and feed production (2021)

10. S.A. Kononova, E.A. Fedulova, Economy of agricultural and processing enterprises, 1, 12-17 (2018) (In Russian.)

11. L.A. Latysheva, T.G. Gurnovich, Journal of Economy and entrepreneurship, 12-3 (53), 384-389 (2014) (In Russian.)

12. S. Polbitsyn, Economy of Region, 15(1), 298-308 (2019) DOI: 10.17059/2019-1-23 (In Russian)

13. V. Surovtsev, Yu. Nikulina, Dairy News: novosti molochnogo rynka kazhdyy den'. URL: $\quad$ https://www.dairynews.ru/news/srednesrochnye-perspektivy-razvitiyaproizvodstva-.html?sphrase_id=5911691 (appeal date: 15.10.2019) (In Russian.)

14. C. Leroux, B. Tisseyre, Precision Agriculture, 20(3), 562-590, (2019) DOI: 10.1007/s11119-018-9598-x.

15. R. Finger, S.M. Swinton, N.E. Benni, A. Walter, Annual Review of Resource Economics, 11 (1), 313-335 (2019) DOI: 10.1146/annurev-resource-100518-093929. 